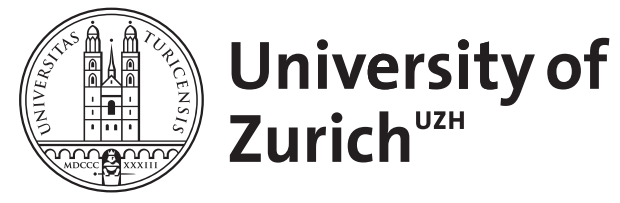

Zurich Open Repository and Archive

University of Zurich

University Library

Strickhofstrasse 39

CH-8057 Zurich

www.zora.uzh.ch

Year: 2014

Neo-Confucianism and industrial relations in Meiji Japan

Lottanti von Mandach, Stefania

Posted at the Zurich Open Repository and Archive, University of Zurich

ZORA URL: https://doi.org/10.5167/uzh-100145

Journal Article

Originally published at:

Lottanti von Mandach, Stefania (2014). Neo-Confucianism and industrial relations in Meiji Japan. Journal of Management History, 20(4):387 -408. 


\section{Journal of Management History}

Neo-Confucianism and industrial relations in Meiji Japan

Stefania Lottanti von Mandach

\section{Article information:}

To cite this document:

Stefania Lottanti von Mandach , (2014),"Neo-Confucianism and industrial relations in Meiji Japan", Journal of Management History, Vol. 20 Iss 4 pp. 387 - 408

Permanent link to this document:

http://dx.doi.org/10.1108/JMH-07-2013-0031

Downloaded on: 20 October 2014, At: 05:55 (PT)

References: this document contains references to 88 other documents.

To copy this document: permissions@emeraldinsight.com

The fulltext of this document has been downloaded 20 times since 2014*

\section{Users who downloaded this article also downloaded:}

(2005),"List of Contributors", Advances in Bioethics, Vol. 8 pp. vii-viii

Jim Smith, (1993),"Japan \# myth or miracle?", The TQM Magazine, Vol. 5 Iss 2 pp. -

Sam Kusumoto, (1993),"The Last Word: Japan: Behold the Sun", Journal of Business Strategy, Vol. 14 Iss 5 pp. 64-64

Access to this document was granted through an Emerald subscription provided by 468523 []

\section{For Authors}

If you would like to write for this, or any other Emerald publication, then please use our Emerald for Authors service information about how to choose which publication to write for and submission guidelines are available for all. Please visit www.emeraldinsight.com/authors for more information.

\section{About Emerald www.emeraldinsight.com}

Emerald is a global publisher linking research and practice to the benefit of society. The company manages a portfolio of more than 290 journals and over 2,350 books and book series volumes, as well as providing an extensive range of online products and additional customer resources and services.

Emerald is both COUNTER 4 and TRANSFER compliant. The organization is a partner of the Committee on Publication Ethics (COPE) and also works with Portico and the LOCKSS initiative for digital archive preservation.

*Related content and download information correct at time of download. 


\title{
Neo-Confucianism and industrial relations in Meiji Japan
}

\author{
Stefania Lottanti von Mandach \\ Institute of Asian and Oriental Studies, University of Zurich, Zurich, \\ Switzerland
}

\begin{abstract}
Purpose - This paper sets out to explain the poor nature of industrial relations in Meiji Japan (1868-1911), especially the puzzling lack of Neo-Confucianist values.

Design/methodology/approach - This paper combines two approaches. First, it draws on and scrutinizes the major literature. Second, it uses a case approach.

Findings - First, we find that a widely accepted assumption used in many management (and other) studies on Japan, namely, that Neo-Confucianism was institutionalized in Tokugawa Japan (1603-1867), is distorted. Second, we find that the poor nature of labor relations in Meiji Japan can be explained by and is the product of a multitude of factors, both indigenous and imported from abroad.

Originality/value - First, this paper provides a novel explanation for the poor nature of labor relations in Meiji Japan. Second, this paper corrects a widely held assumption on Japan that is frequently used in management studies.
\end{abstract}

Keywords Japan, Neo-Confucianism, Labor Relations, Meiji era, Samurai, Management studies

Paper type General review

\section{Introduction}

Japan is famed for its industrial relations. One common explanation links its harmonious nature to a centuries-old Neo-Confucianist heritage institutionalized in Tokugawa Japan (1603-1867) with values such as loyalty, filial piety, reciprocal obligation, harmony and duty (Bellah, 1985; Hofstede and Bond, 1988; Furuya and Shiina, 1991; Hill, 1995; Fujimori and Ouchi, 1996) that influence Japanese economic behavior in general and labor relations in particular (Long and Seo, 1977; Pascale and Athos, 1981; Sours, 1982; Bellah, 1985; Hofstede and Bond, 1988; Subhash, 1990; Furuya and Shiina, 1991; Whitehill, 1992; Hill, 1995; Fujimori and Ouchi, 1996; Boardman and Kato, 2003; Blind, 2012)[1].

Against this background, the poor nature and the apparent lack of Neo-Confucianist values in Meiji Japan (1868-1911) are puzzling. Contrary to what one might expect, industrial relations were far from "warm master-servant relations" based on a Neo-Confucianist tradition. Employers cared little for the well-being of their employees. Employee morale was low, and absenteeism, sabotage, strikes and desertions were frequent. Bureaucrats claimed that business leaders were only motivated by profits and did not consider the well-being of their employees, leading to excessive rates of turnover that were inimical not only to the interests of the enterprises but also to the economic progress of Japan as a whole (Taira, 1962; Gordon, 1998). Overall, "there was then so little of the feeling of loyalty between employer and worker which is said to be characteristic of the employment relationships fifty years later" (Taira, 1962, p. 155).

\footnotetext{
Journal of Management History Vol. 20 No. 4,2014 pp. $387-408$

(C) Emerald Group Publishing Limited 1751-1348 DOI 10.1108/JMH-07-2013-0031
} 
JMH

20,4

388

How can these observations be explained? One conceivable thesis is that culture in general and the Neo-Confucianist tradition in particular simply didn't matter. In fact, many economists have struggled to accept culture as a possible explanatory variable, mainly due to the broad notion of culture and the difficulty to design testable hypotheses (Guiso et al., 2006). However, recent attempts to overcome this impasse (for an overview of recent papers, see Guiso et al., 2006; Gong et al., 2013), as well as the vast contributions by management theorist and sociologists on the effect of culture on economic and political outcomes, leads to a rejection of this null hypothesis (DiMaggio, 1994; Dyck et al., 2012; Preble and Hoffman, 2012).

Ornatowski (1996) hypothesizes that Neo-Confucianist values didn't matter temporarily. He argues that Neo-Confucianism somehow declined in Meiji Japan due to its close relationship to the ideology of the Tokugawa regime and the strong Westernizing tendencies of early Meiji era policies and thought and that it first had to re-enter the workplace.

Morishima (1982), on the other hand, writes Neo-Confucianist values did, indeed, play a role, but that only the samurai (warrior) elite, not the commoners (i.e. peasants, artisans and traders) espoused Neo-Confucianist values. Because former samurai as well as many merchants and rich peasants established new businesses in early Meiji Japan, Neo-Confucianist values had not yet spread to all labor-management relations.

We propose a different explanation and argue that little of a Neo-Confucianist heritage is detectable in Meiji labor relations because Neo-Confucianism wasn't institutionalized in Tokugawa Japan in the first place. While research suggests that Neo-Confucianist values were institutionalized eventually post-Meiji Japan, a sound analysis of their factual historical development is necessary prior to analyzing Neo-Confucianist influences on present-day Japanese economic behavior and institutions. As Smith and Smith (2011, p. 282) write in their article on the biased use of the construct of the Protestant Work Ethic in management research, "Widely accepted assumptions about key constructs unconsciously drive how scholars think and do research. [...] If a basic assumption is distorted, research utilizing this assumption is suspect". Thus, to scrutinize the historical development of Neo-Confucianism in Tokugawa Japan and thereby a key assumption of much research about Japan, is one objective of this paper. In addition, we contribute to the body of knowledge by taking a fresh look at labor relations in Meiji Japan and providing a novel explanation for their poor nature.

We proceed as follows. In a first step, we address the question of institutionalization of Neo-Confucianist values in Tokugawa Japan. We base our claim that NeoConfucianist values were not institutionalized in Tokugawa Japan on two main arguments, namely, on the analysis of the process and extent of institutionalization of Neo-Confucianism in Tokugawa Japan, and on a case study that illustrates the consistent lack Neo-Confucianist values in contemporary (economic) behavior even in the case of the ruling samurai class. As we will show, the findings from these arguments fit well with existing research on the nature of the Tokugawa rule, on the one hand, and invented traditions in Japan, on the other hand, indicating that our case study does not represent an exception to the rule. In a second step, we identify a coherent set of factors explaining the poor nature of labor relations in Meiji Japan.

This article unfolds as follows. We start with a brief description of the political structure and institutions (of which Neo-Confucianism was one) the Tokugawa rulers 
resorted to in order to achieve political stability in Chapter 2. In Chapter 3, we show that the efforts by the Tokugawa rulers to anchor Neo-Confucianists values were severely Neo-Confucianism limited and so was, as a consequence, the institutionalization of Neo-Confucianism, even among the ruling samurai class. A case study in Chapter 4 illustrates our findings, which we link to existing research on the nature of the bakufu-han (Tokugawa rulers and their vassals) relationship and on the invented traditions[2] of modern Japan in Chapter 5. In Chapter 6, then, we develop a coherent set of explanatory factors for the poor labor relations, thereby explaining the questions raised in Chapters 4 and 5 . In Chapter 7, we summarize our main findings and highlight areas for further research.

\section{Tokugawa Japan}

The Tokugawa state was composed of a central directing force, the bakufu (or shogunate) at the top and number of local authorities that administered the land and the people on behalf of the bakufu. The bakufu was located in Edo and headed by the shogun. The shogun was the authority over national defense, foreign affairs and legislation for the entire country. He controlled the minting of money, the standardization of weights and measures and the regulation of trade. The bakufu also controlled the cities of Edo, Kyoto, Nagasaki and Osaka. The rest of the country (i.e. four-fifths of the land) was split into han (domains) that were strategically distributed among approximately 250 daimyō (vasalls). These domains were called upon to cooperate in connection with building projects, but they were not taxed by the bakufu. Economic policies were localized, i.e. domain-centered. Domains could use the income generated through taxes within their domains for their own expenses. By and large, the domains were nearly independent states with their own armies, administrative and law codes, tax systems and tax codes (Jansen, 2000, p. 33).

During Tokugawa Japan, the bakufu constructed a number of formal institutions to achieve political stability. For the bakufu, the daimyō were the main threat because they possessed territorial and military resources. Weakening and disrupting the daimy $\bar{o}$ as a group was the main preoccupation of the early Tokugawa rulers. To control the daimyo, a system known as sankin kōtai (alternative attendance) was introduced. Nearly all daimyō had to alternate spending a year in Edo and a year in their domains while their families remained permanently in Edo. There was great expense involved in maintaining residences in both Edo and their domains, as well as in traveling to and from Edo on a regular basis. This arrangement prevented the daimyo from accumulating too much financial power (Henshall, 1999, p. 52). As an additional measure of stability, the Tokugawa rulers adopted a policy of national seclusion, leading to the virtual closing of Japan for 150 years, and implemented a rigid Neo-Confucianist social order known as shinōkōshō (Yoshimura, 2003). Shinōkōshō was a four-tiered caste system - "warrior-peasant-artisan-merchant" - in descending order of status. At the top was the warrior (samurai) class, a small educated ruling class that performed all military and political functions and accounted for approximately six per cent of the population (Henshall, 1999, p. 51). Peasants ranked second, higher than artisans and merchants because, in Neo-Confucianist terms, they were regarded as the essential producers. They nurtured the country and thereby provided income for the samurai. The artisans, ranking third, changed the form of things and were, therefore, useful. The merchants only moved things around and made them available for 
$\mathrm{JMH}$

20,4

390 purchase. Accordingly, they were the least important of the classes. Each individual was expected to assume the duties that were assigned by birth and occupation.

\section{Neo-Confucianism in Tokugawa Japan}

According to historiographical tradition, Neo-Confucianism was put to use by Tokugawa Ieyasu as an ideological construct (Ooms, 1985, p. 297). It provided the foundation and convenient justification for the system of strict social prescriptions, the shinokosho. Three mechanisms undergirded the authority structure of society. First, Neo-Confucianism rested on the useful premise that there existed a natural division of society by status and vocation. Second, it emphasized loyalty to superior authority and, hence, rationalized submission to the authority of the daimyo and various unit heads as matters of principle. Third, Neo-Confucianism made rule by status acceptable. In contrast to rule on the basis of personal dominance, the daimyo exercised authority on a generalized and impersonal basis under codified laws and regulations rather than on the basis of personal or customary prerogative (Hall, 1974, p. 47). Therefore:

Ieyasu Tokugawa's first task was to restore peace and purpose throughout the country. One of the ways he did this was to adopt Confucianism as the official philosophy of his government. Confucian philosophy provided Ieyasu with the justification for the organizational structure he needed to rule Japan and the guidelines for proper behavior his citizens were to follow (Boardman and Kato, 2003, p. 321).

As we will explain in the following, the problem with such account is twofold. First, Neo-Confucianism did not serve as the state ideology from the beginning of Tokugawa Japan (Ooms, 1985, p. 76; Bodart-Bailey, 1993, p. 294). Second, the bakufu did not have adequate means and channels to promote Neo-Confucianism as the state ideology to all classes later in the era. Hence, institutionalization was limited with regards to both time and scope.

Early Tokugawa shoguns, never perceived Neo-Confucianism as a tradition that deserved specific support. Tokugawa Ietsuna, the fourth shogun, even persecuted certain Neo-Confucianist scholars (Bodart-Bailey, 1993, p. 294).

The position of the Neo-Confucianist scholars improved somewhat between 1690 and 1709 under the administration of the fifth Tokugawa shogun Tsunayoshi (1646-1709), when the bakufu encouraged the practice of Neo-Confucianism (Bodart-Bailey, 1993, p. 312). However, for Tsunayoshi, both Buddhism and Neo-Confucianism had shortcomings and could not serve as philosophical systems alone; therefore, both teachings were to be practiced in conjunction (Bodart-Bailey, 1993, p. 306).

Despite Tsunayoshi's patronage of Neo-Confucianism, restrictions were imposed on Neo-Confucianist scholars. Ooms (1984, p. 61) argues that as late as the Kansei Reforms (1788-1793), Neo-Confucianist scholars (jusha) were no more than "applicants, selling their ideological wares and longing for a bakufu patent". The jusha took themselves very seriously as the carriers of scholarly morality, but they were never part of the power structure they served. Although Neo-Confucianist scholars served the shogun by appointment, and advised and educated some of the upper reaches of warrior society (Yoshioka, 1993), they collectively struggled with the frustration resulting from the fact that the ideals of an earlier and imagined past, in which morality and action were consistent, did not correspond with the present society of which they were a part (Jansen, 2000). They attempted to prescribe remedies for social and political maladies, such as the abolition of the institution of sankin kotai and the return of the samurai to their land 
because they regarded the sankin kottai as the root of all evil that had led to urbanization, the spread of commercialism and merchant growth (Uematsu, 1995). None of this happened, and the jusha were well aware that they were marginal to the decisions and concerns of the ruling figures (Jansen, 2000, p. 195). Despite its initial disdain for Neo-Confucianist scholars, later in the era, the bakufu sought its educational creed in Neo-Confucianism to secure its regime (Song, 1970, p. 145). It lacked, however, the means to institutionalize Neo-Confucianist norms from top down within the Tokugawa society. There was no national education system in place; therefore, there was no standardized Neo-Confucianism and enforced curriculum, and none was created during the Tokugawa era (Rubinger, 1986, p. 195).

There was some type of education system in place, but it was far from universal. Education was unsystematic and was a patchwork of different teachers with various experiences. It consisted of a loose configuration of discontinuous and primarily private arrangements that were not under the control of a public authority (Rubinger, 1986, pp. 195-201).

For the education of commoners, terakoya was the most important institution, although it was not the only one (Tanaka, 1990). Shinto shrines and private institutions shared the educational function. In the Tokugawa period, terakoya lost their religious function and became entirely secular. This was a voluntary organization, unregulated by the Government that taught children of both sexes. Teaching was vocationally oriented and was concerned with the practical aspects of the commoner's life, focusing on reading, writing and calculation. The number of terakoya in the country was approximately 15,500 before Meiji Restoration. They were found mainly in towns, and the terakoya in villages were attended by the upper strata of the villages - if at all (Kobayashi, 1965, p. 292; Song, 1970, p. 145; Dore, 1965, p. 252). The ordinary peasants had neither the time nor the money for education (Kobayashi, 1965, pp. 292-293; Henshall, 1999, p. 51). The merchants, in contrast, increasingly recognized that the investment of time and money into education was economically worthwhile, and the value of education was expounded in contemporary moral books for commoners (Komiyama, 2006).

It was only towards the end of the 18th century that both the bakufu and the han began to pay attention to the education of commoners. They established gogaku with the goal of countering political and economic unrest, which was growing among the commoners (Jansen, 2000, p. 234). The gogaku curriculum emphasized a moral indoctrination based on Neo-Confucianist values. It is estimated that approximately 130 gogaku existed throughout the country, a fairly small number compared to the number of terakoya (Kobayashi, 1965, p. 293). Thus, the bulk of the commoners never enjoyed any type of formal moral education on Neo-Confucianist ethics.

Samurai education occurred in three types of institutions: bakufu schools, han schools and private schools. The primary purpose of bakufu and han schools was the moral training of the hereditary elite (Rubinger, 1986, p. 197). The samurai were taught subjects necessary for rulers; this distinguished the samurai from the commoners in peacetime when distinction through military leadership was not possible. Thus, Neo-Confucianist classics were important not only because of their content but also because this knowledge was a status symbol (Kobayashi, 1965, p. 291). The classics were taught not for intellectual pleasure but as training for dedicated service and duty to the regional and ultimately political community (Jansen and Stone, 1967, pp. 210-211). 
$\mathrm{JMH}$

20,4

392

The 21 bakufu schools were under the direct control of the bakufu and differed in their educational functions. The highest institution of Neo-Confucianist learning was the Hayashi Confucian Academy in Edo (Kobayashi, 1965, p. 290; Dore, 1965, p. 15ff). It was founded by Hayashi Razan in 1630 and was subsequently run by the Hayashi family. From 1798, it was managed under the auspices of the Tokugawa government, which renamed it the Shōheizaka Academy (Shōheizaka Gakumonjo) (Sawa, 1999). The courses taught at the school were Neo-Confucianist literature, history and composition. The school served as the center of Neo-Confucianist doctrine and produced scholars and learned officials of the Tokugawa government (Kobayashi, 1965, p. 290; Paramore, 2012).

Within each han, there were one or more han schools (hankō, hangaku or hangakkö). In the early Tokugawa period, han schools emphasized Neo-Confucianist teaching. In the 18th century, practical subjects, such as applied mathematics, military science, medicine and astronomy, were included in the curricula of lower-ranking samurai. Private schools (shijuku) for samurai, some of them independent and some supported by local government, typically specialized in particular curricula, such as Neo-Confucianist learning, Japanese studies or Western languages.

Whether the bakufu's efforts to institutionalize Neo-Confucianist values among the samurai elite also bore fruit, is a different question. When reading the writings of Ogyu Sorai (1666-1728), born a son of a samurai and one of the most influential Neo-Confucianist scholars in Tokugawa Japan, the success of such efforts appears limited. In his "Discourse on Government" (seidan), written in 1726-1727, Sorai discusses the negative side effects of the economic growth and spread of commercialism that occurred during Tokugawa Japan. He deplores the lack of Neo-Confucianist ethics in contemporary economic behavior, the competitive mentality within society, the bourgeois spirit of excessive consumption and the focus on "having" rather than "being" that had infiltrated society because even the warrior class did not adhere to Neo-Confucianist values (Lidin, 1999, p. 37).

A good case study to illustrate this issue is the disobedience and lack of loyalty displayed by the daimyo toward the bakufu with regard to the marketing of domain goods (see next section)[3]. In Neo-Confucianist ideology, loyalty to one's superior is not only a sacred duty but is also an absolute obligation for religious salvation (Hill, 1995, p. 123). The Japanese Neo-Confucianist thinkers of the Sorai school particulary stressed that the basis of good government was individual feudal relations of loyalty (Paramore, 2012, p. 32). In theory, each daimyo, i.e. (house) had a loyalty-dependence relationship with the house of Tokugawa, which was at the apex of the vertical hierarchy. The bakufu's orders had to be followed and the daimyo were expected to be loyal to the shogun in every way. It was in the Tokugawa shogunate's best interest to propagate such beliefs, and, according to various accounts, it was successful in doing so (Bellah, 1985; Maruyama, 1974).

\section{The case of the marketing of domain goods}

The daimyo had sufficient autonomy in administering their holdings with regard to economic and fiscal affairs as long as their policies did not conflict with those of the bakufu (Nakamura and Miyamoto, 1982, p. 248).Before 1800, the aims of both the bakufu and the daimyo to tax as much of the production of their people as possible while maintaining and possibly increasing the productive capacity of their territories did not 
conflict with one another. By the first quarter of the 18th century, although the expansion of paddy acreage had given many daimyō a larger tax base, nearly all Neo-Confucianism domains were spending more than they could collect in taxes, mainly due to the system of sankin kotai and the occasional extraordinary levies demanded by the shogunate. To increase their revenues, the domains actively encouraged the development of handicraft industries and agricultural products that could be sold inside their domains and to the national, bakufu-controlled market. They also established domain monopoly marketing boards called senbai shiho, a measure to place multiple types of specialty products produced within their han under the governmental monopoly of their han (Takenaka, 1969, p. 150). With the establishment of domain monopoly marketing boards, all commercial activities within the han apart from small-scale local peddling were controlled by authorized castle town merchants, who were granted privileges in return for their commercial and financial services.

By 1800, production had developed to such a point that marketing these products led to a chronic conflict between the domains and the bakufu. The domain marketing boards, which sold to both the local market and the national market, competed with the distribution system that was controlled by the bakufu (Crawcour, 1989, p. 579). In theory, the domains were not allowed to sell directly to bakufu-controlled urban consumption centers. Trade between the han and the bakufu territories had to pass through official channels in Osaka or Edo and was handled by authorized city merchants. In practice, however, around 1820 the domains started to sell their products outside of the official channels wherever they could secure the best price. Because the bakufu bought the products at fixed prices, the domains attempted to avoid the Osaka route and marketed products through other channels or directly to Edo. Consequently, shipments to Osaka, the commercial center, fell by 30 per cent between 1820 and 1840 . Needless to say, this provoked strong resistance from the Osaka city merchants who were struggling to maintain the privileges granted by the bakufu and who wanted to prevent the domains from selling directly to urban consumption centers controlled by the bakufu. The decreasing shipments to Osaka and the increasing profits of the domains and rural merchants not only threatened the officially authorized city merchants but also weakened the shogunate's ability to control national commerce. In a report prepared under the direction of Osaka City Magistrate, Abe Tōtōmi no Kami, in 1841-1842, the domains were blamed for diverting goods away from Osaka because they marketed their products elsewhere and prevented private shipments to Osaka. Only when the domains found it convenient, the report said, did they market their goods in Osaka, but then they used their monopoly power and threats of going elsewhere to secure higher prices. The bakufu reacted and, attempting to reduce both its own expenses and the profits of the domains, ordered a general 20-per cent price cut on goods in Edo and Osaka, as well as a cut in wages and rents. It hoped that these reductions would eventually lower the rates paid to the producers, thereby reducing the attractiveness of industry and trade as opposed to agriculture. Prices, however, did not fall as significantly as expected. Demand for consumer goods was no longer confined to the large, $b a k u f u$-controlled consumption centers but had developed in many other parts of the country. Because sales could be made there, the domains and rural businessmen were not prepared to cut their margins. Goods were simply diverted from bakufu-controlled consumption centers to the country-side markets that had developed (Crawcour, 1989, p. 596). 
$\mathrm{JMH}$

20,4

394

\section{An imagined past of Neo-Confucianist tradition}

Thus, although in theory each daimyö i.e. (house) had a loyalty-dependence relationship with the house of Tokugawa whose orders had to be followed, in practice, the daimyo gave preference to the economic interests of their domains rather than displaying loyalty to the bakufu, even after the bakufu's intervention. The fact that the daimyo could do so repeatedly without serious consequences confirms Jansen (2000, p. 59) view the bakufu-han relationship was more symbiotic than hierarchical and antagonistic. In theory, the daimy $\bar{o}$ held their domains in trust and not as private possessions, and domains could be revoked for infractions of shogunal edicts. Over time, however, reassignments and confiscations of daimyō lands diminished, tenure became more secure and the bakufu-han relationship became more symbiotic because both parties shared an interest in keeping the countryside under control (Jansen, 2000, p. 54). The bakufu provided the domains with guarantees against disruption from below. When the number of rebellions grew in the 18th century, the bakufu frequently ordered neighboring domains to help suppress the insurrections. Village headmen and village officials, who were peasants and had the largest stake in local trade and industry, were the leaders of uprisings and petition movements directed against monopolies. The bakufu also assisted the domains during emergency food shortages resulting from bad crops. In addition, the bakufu frequently outsourced the administration and taxation rights of shogunal lands scattered throughout the country to han whose location made it easy to supervise the land (Jansen, 2000, p. 43). Thus, Japan was far from being administered in the ideal way envisaged by the Confucians of the Sorai school, namely, a strictly hierarchical government that was based on the sanctity of filial and loyal relationships between the ruler and the vassal (Paramore, 2012, p. 32). However, as Lidin (1999, p. 15) writes, it was exactly such ideal Neo-Confucianist system and society, although it never existed, to which all "later Confucian social utopianism" referred.

The first time such an imagined past of Neo-Confucianist tradition was invoked on a large scale was in Meiji Japan. Via the Imperial Rescript on Education of 1890 Neo-Confucianist values were restated and elevated to a fundamental element of compulsory public education and were used to buttress a powerful modern state with a nationalistic ideology (Ornatowski, 1996, p. 575). The Imperial Rescript on Education not only made schooling mandatory and universal but also required schooling to inculcate Neo-Confucianist values, especially loyalty to the emperor (Ham, 2004). Neo-Confucianist values were also invoked in the economic sphere. On the eve of World War I (1914-1918), the Japanese government and the business and intellectual elite had accepted the idea that the basic virtues of management in Japan were a paternalistic leadership style and "warm master-servant relations" based on a unique Neo-Confucianist tradition, on the one hand, and the capacity to ensure a harmonious social order rather than the individual pursuit of profits, on the other hand (Gordon, 1998, p. 23). The pursuit of wealth was only legitimized if its ultimate aim was public benefit, i.e. the nation. This concept resembles the Christian tradition and its disdain for the pursuit of secular self-interest before the spirit of capitalism emerged and the pursuit of self-interest became socially legitimized in the 18th century (Gerde et al., 2007).

Such agreement, however, was not easily reached. It was preceded by a debate about worker protection that began in 1896 among bureaucrats, politicians and business leaders. For the bureaucrats, factory legislation was necessary because excessive rates of turnover would be inimical not only to the interests of the enterprises but also to the 
economic progress of Japan as a whole. They claimed that turnover rates were high because business leaders were only motivated by profits and did not consider the Neo-Confucianism well-being of their employees. Working conditions were poor, wages were low and many factory workers returned to the countryside sick and disabled (Taira, 1962, p. 154). The business leaders, in contrast, argued that by honoring the ancient "beautiful customs" of obedience and loyalty from below and sympathetic understanding from above, problems such as resistance to factory discipline, low morale, absenteeism, sabotage, strikes and desertions that characterized the large majority of factory workers could be solved. Legislation would undermine the emotional basis of the old, integrated social order by legally sanctioning the interests of the workers (Gordon, 1998, p. 21). Whereas Ornatowski (1996, p. 572) argues that "certain Confucian-derived values [...] were [...] utilized instrumentally by Japanese industrialists and government bureaucrats [...] as they were reflective of these elites' own personal values", Gordon (1998, p. 19) states that to the business elite, invoking a Neo-Confucianist tradition was merely rhetorical. It ultimately served their profit-oriented ends because they feared that labor legislation would ban night work for female labor and child labor, thereby restricting factories' operations by cutting-off a critical source of workers and leading to higher costs[4]. Thus, an invoked Neo-Confucianist tradition in which they placed their self-interest served as moral cover for their actions, or in this case, their inactions[5]. The latter interpretation is supported by none other than Shibusawa Eiichi, one of the most important industrialists of the Meiji and Taishō eras (1912-1926) and an ardent advocate of the application of Neo-Confucianist values to the economic sphere (Ornatowski, 1998, p. 354). For Japan to prosper economically, it was necessary to "reshape the character of Japanese businessmen away from the obsequious and cunning Tokugawa merchant toward a public-minded and well-educated modern businessman" (Ornatowski, 1998, p. 356) who subordinated private interests to the welfare of the nation.

The debate between bureaucrats, politicians and business leaders never led to a consensus on what particular practices would actually define these "warm master-servant relations" (Gordon, 1998, p. 23). The parties eventually agreed on a Factory Law that was passed in 1911, with a diluted version of this law taking effect in 1916 (Gordon, 1998), stipulating a minimum set of standards for employment (Yamamura, 1997). In the 20 years after the Factory Law was passed, the idea that a native Neo-Confucianist tradition was relevant to industrial relations largely disappeared from public discussion before it eventually reemerged in 1931 (Gordon, 1998, p. 26).

\section{A tentative explanation for poor labor relations in Meiji Japan}

Chapter 5 leaves us with two important questions. First, what, if not Neo-Confucianism, shaped the cultural underpinnings of the samurai class in Tokugawa Japan? Second, how can the poor labor relations in Meiji Japan be explained?

The first question is not easy to answer. A variety of religious movements and intellectual currents have been linked to the shaping of the samurai's world view. To scrutinize them all would be beyond the scope of this article. What is more, evidence for the importance of these influences is less clear than one might assume[6]. In light of the vast literature on the influence of religion on economic behavior in the western hemisphere (Weber, 1958/1920; Gerde et al., 2007; Tackney, 2009; Jacobs, 2010: Rost et al., 2010; Dyck et al., 2012), one potential source of influence on the samurai world view 
$\mathrm{JMH}$

20,4

396

that deserves closer attention is religion, in particular Buddhism. Like Confucianism, Buddhism also originated outside of Japan (Kawaguchi, 2010, p. 54). Buddhism, however, was more influential and became the state religion in the 6th century. It evolved from court Buddhism to a religion that influenced all layers of society. Buddhist doctrines of karma, rebirth and the denial of the reality of corporeal existence became a basic worldview throughout Japan (Jansen, 2000, p. 216). What is more, Buddhism was more intimately related to the Tokugawa power structure than Neo-Confucianism was. Daimyō patronage of Buddhist temples was common, but not necessarily out of faith. Samurai-Buddhist relations were influenced by long-standing undercurrents of tension and mistrust and samurai applied extensive regulations to Buddhist temple communities with doctrines and policies denying shogunal and daimyō authority. Nevertheless, the daimyō continued to use Buddhist services, such as ancestor veneration through Buddhist auspices, and to patronize temples as a means of asserting the legitimacy of their houses by situating their house within a larger system of social practice (Vesey, 2004).

Buddhism, specifically various Buddhist movements and schools, also provided spiritual and practical guidance with regard to economic life and are therefore of vital interest for our second question, the issue of labor relations. From medieval Japanese Buddhism, for example, an ethic of self-discipline and ascetic restraint on consumption originated. The Nichiren movement, a school of Japanese Buddhism named after its founder, Nichiren (1222-1282), emphasized asceticism and discipline and was the main urban religion among townspeople in medieval Japan (Collins, 1997). The samurai preferred Zen Buddhism. In Zen Buddhism, work is regarded as an opportunity for meditative practice, and Zen stresses reliability and diligence in performing one's occupation according to one's social status. Through divisions of labor, people are interdependent and benefit from each other as long as their occupations are useful to society and economic gains are not made for their own sake (Kawaguchi, 2010). Although Zen Buddhism in general and the samurai and Zen monk Suzuki Shōsan (1579-1655) specifically are often referenced by scholars seeking sources of the Japanese work ethic (Hull and Bold, 2013), they add little to our understanding of poor labor relations in early Meiji Japan. Nevertheless, Buddhism is, as we will elucidate, central to understand industrial relations in Meiji Japan. In the following section, we propose a novel, albeit preliminary explanation for this question.

\subsection{Explaining poor labor relations in Meiji Japan}

Whereas Buddhist teachings sought to influence people's perceptions of work and work ethics in a normative way by stressing the meditative character of work as well as the importance of diligence and discipline, Buddhist religious organizations affected the Tokugawa economy in a very tangible and concrete way. As Collins (1997) writes, Oda Nobunaga (1534-1582) and Toyotomi Hideyoshi (1537-1598), both preeminent daimyō of the Sengoku era (1477-1573), transferred a capitalist dynamic that had been developed by Buddhist religious organizations to the secular economy by conducting a policy of monastic property confiscation. In medieval Japan, Buddhist organizations had constituted the leading sector of economic growth. These organizations were diverse, and not all of them contributed equally to economic growth in the Middle Ages. However, all branches of Buddhism eventually became commercialized, and by the Sengoku era, they had all become part of the productive religious economy (Collins, 
1997, p. 853). Buddhist temples were entrepreneurial organizations in Japan that, for the first time, combined labor, capital and land with the goal of enhancing production. Neo-Confucianism Collins (1997) infers that the monasteries' prosperity and their methods established a lead that was followed by the daimyo during the Sengoku era. Rather than being a mere extractor of feudal rents, the daimyo adopted rational practices of land reclamation, water control and double cropping, leading to a substantial increase in agricultural output between 1550 and 1650. Thus, Buddhist capitalism catalyzed secular capitalism, and in Tokugawa Japan, secular market capitalism outgrew religious capitalism.

Wage labor became a central element of this secular market capitalism. Whereas in the 16th century, conscripted peasants, artisans and hereditary domestic servants in samurai households made up the traditional labor force in non-agricultural occupations, in the 17th century, a major transformation of work and working relations took place that gathered momentum after 1650 (Mathias, 2011). Wage labor emerged, and by 1700, one-fifth to one-third of the population in the cities and towns consisted of hired servants, shop hands and manual laborers (Leupp, 1992, p. 176). The shift from corvée labor to wage labor was brought about by the enormous demand for labor due to the simultaneous realization of large infrastructure projects. This made the Tokugawa shogunate realize that this labor demand could not be met by corvée labor alone without endangering agricultural production and, hence, tax income (Leupp, 1992; Mathias, 2011).

Urban growth also drove the expansion of an urban working class. These workers were employed by the shogunate, its officials, the daimyo, and merchant and artisan households (Leupp, 1992; Mathias, 2011). The urban workers were farmers who had flocked to the cities in the search for a way to make a living. According to Rozman (1974), Edo grew by 10,000 immigrants a year during the first half of the 17th century and by approximately 15,000 in the second half of the 17 th century.

Not surprisingly, according to the ruling class, the peasant migrants were lazy, had a selfish desire to better their lot, shirked their appointed tasks (i.e. producing rice for the ruling class) and were merely "looking for a free ride" (Leupp, 1992, p. 66). Neither the wage laborers' work ethic nor the quality of master-servant relations matched the ideal as, for example, celebrated in popular fiction or normative contemporary writings (Leupp, 1992, pp. 70ff.). Takemura (1997, p. 194) notes that "Ninomiya [Sontoku, see above; the author]'s thought does not represent the idea of work prevalent in the advanced areas [...]". Similarly, casual, short-term employment in the trading houses of Edo differed substantially from Ishida Baigan's ideas. As commerce expanded during the 18th century, so did the hiring of short-time labor for unskilled or semi-skilled tasks (Mathias, 2011). An increasing number of workers did not remain in their positions long enough to develop the idealized sentimental bonds with their employers. In favor of the urban workers was the fact that in Tokugawa Japan, there was a consistently high demand for wage labor, and nearly anyone could find employment, regardless of their attitude and quality of work (Leupp, 1992). Crimes committed by paid workers were seen as a direct consequence of the loosening bond between master and servant. Running away was the most common crime. Other crimes included workers' violence, fighting or theft. Mutual suspicion and hostility were in evidence, including masters physically abusing employees they deemed lazy. The fact that each worker legally required a guarantor ensuring that the worker adhered to the employment contract indicates that labor relations were far from the ideal depicted in Zen Buddhism, 
$\mathrm{JMH}$

20,4

398

Neo-Confucianism or the other schools introduced above. Guarantors were held liable for the repayment of wages in case the worker absconded. In many cases, a single employee had several guarantors, all of whom were held liable if the worker did not meet his contractual obligations (Leupp, 1992; Mathias, 2011). Whether this was the outcome of the workers' work ethic or merely a reaction to employment conditions is an open question. In any case, the perception of these urban workers in Tokugawa Japan, who later made up one group of the industrial labor force in the Meiji era, was hardly positive.

The second group making up the industrial labor force in Meiji Japan was farmers newly migrating to the cities. In Tokugawa Japan, the attitude of the ruling class toward farmers was by no means more favorable than the attitude toward the urban working class, as contemporary writings reveal. These writings either reflect the very mundane desire of the ruling class to secure their income or the writer's ideological support of the class system, the shinokosh $\bar{o}$ or both. Theories on the way to rule farmers were proposed by, for example, Kumazawa Banzan (1619-1691), a Neo-Confucian scholar, and Honda Masanobu (1538-1616), a samurai himself. His book Honsaroku ("The Record of Honda Masanobu"), which was oriented toward the ruling class, stated that the farmers must be ruled wisely because they were the source of income for the samurai class. Farmers should be controlled by allowing them to possess just enough to live upon, not more or less. Kumazawa Banzan expressed similar sentiments and recommended keeping farmers diligent and safe from starvation to ensure rich harvests. Farmers should have neither too much nor too little for their living. Furthermore, in Kumazawa's view, the individual farmer was ignorant and should be pitied. Thus, in a nutshell, "the keynote of the agricultural policy followed by the Tokugawa Shogunate was 'to keep farmers alive but not allow them to live in comfort" (Honjo, 1939, p. 8). The finance superintendent of the 1730s put it more bluntly. Comparing farmers to sesame seeds, he asserted that "the more you squeeze, the more you obtain from them" (Leupp, 1992, p. 7). Adding to the inferior position of the farmers was the fact that samurai were subject to codes of behavior only within their own status group. The majority of law in the daimyo domains consisted of house precepts that regulated the behavior of the warrior-retainers. No laws regulated the samurai's relations with the lower social orders. The samurai were legally free to act violently toward the lower social classes, especially in punishing affronts in matters of personal deference because they had no rights under samurai law (Collins, 1997, p. 857).

Thus, these two groups, the urban wage laborers already residing in the cities and farmers from Japan's hinterland who were newly migrating to the cities, constituted the factory workers in Meiji Japan. Although the Meiji Restoration in 1868 represented a major cesura in political terms with imperial rule restored, work and labor market conditions in the early Meiji era resembled those during the Tokugawa era, as Leupp (1992) has noted. Employers found it difficult to recruit enough workers despite the labor reserve from Japan's hinterland, and they complained, as their counterparts in Tokugawa Japan did, about high labor turnover, employee laziness, a lack of loyalty, absenteeism, and desertions (Taira, 1962). In a nationwide survey on the working and living conditions of factory workers published in 1903 by the Ministry of Agriculture and Commerce, factory managers complained that workers did not distinguish between working and resting time, did not always fully concentrate on their work and attempted to evade supervision to rest, chat with fellow workers or smoke; therefore, factory managers had no other choice than to increase working hours. The Ministry conceded 
that work discipline was lower in Japan than in Europe, but it took into consideration that the long working hours and dire working conditions led to the Japanese workers' lax work discipline (Hashimoto, 2002). Taira (1962) also states that workers had to cope with long working hours and poor working conditions. He explains the dire working conditions by the fact that employers had to contract labor recruiters to tap the labor reserve in the hinterland, leading to soaring recruiting costs that the employers attempted to offset by cutting wages and reducing non-wage expenses that directly affected the welfare of workers, such as housing, eating and recreational facilities, Neo-Confucianism lengthening workdays or speeding processes to exact as much effort from the workers as possible.

The ideas of economic liberalism that were imported reinforced the prevalent attitudes about labor relations and legitimated the poor working conditions, fending off government intervention to regulate the labor and improve workers' conditions[7]. The concept of economic liberalism was made available by translations as well as by original Japanese writings. The first to introduce economic liberalism was Kanda Kōhei (1828-1898). Kanda had learned Confucianism in his youth, but after Perry's visit to Japan he became an ardent student of Rangaku ("Dutch Studies")[8]. In 1862, the bakufu made Kanda an instructor at the Bansho Shirabesho ("Institute for the Study of Western Books") (Horie, 1962). He published two books before the Restoration: the Nōshōben ("On Agriculture and Trade") in 1861 and the Keizai Shögaku ("An Economic Handbook") in 1867/1868. In line with classical economics, he declared that men are, by nature, different from each other; some are lazy, whereas others are industrious. This explains why some grow rich while others remain or become poor. Government intervention would discourage virtue and eventually impoverish the nation (Sugiyama, 1968). Other conspicuous proponents of economic liberalism were Tsuda Masamichi (1829-1903), a law expert and one of the members involved in the drafting of the Meiji constitution (Kiyota, 1966); Taguchi Ukichi (1855-1905), a historian and economist, occasionally referred to as "the Japanese Adam Smith"; Amano Tameyuki (1861-1938), a Japanese politician, educator and economist; and Fukuzawa Yukichi (1835-1901), one of the best-known, most widely studied and most frequently quoted writers of the early Meiji period and the alleged "champion of the 'Japanese enlightenment" (Sugiyama, 1968, p. 327). Like Kanda, Fukuzawa proposed the laissez-faire idea and maintained that to achieve national wealth, the government must not put restrictions on people's activities. What set him apart from the 19th century Anglo-American liberalism, however, was Fukuzawa's explicit contempt for manual labor. Only work that required the use of the heart (i.e. the head) was to be honored in society. Fukuzawa further held the opinion that the source of everything good and edifying in Japan was the former samurai thanks to their family background and tradition. With a few exceptions, he regarded commoners as foolish, spiritless and powerless. Although he failed to criticize class relations during Tokugawa Japan, Fukuzawa's ideas resonated with the most conservative, not the most liberal 19th century Anglo-American thought (Kinmonth, 1978).

It was only toward the end of Meiji Japan that labor relations started to improve. First of all, the necessity of regulating the labor market attracted governmental attention in the late 19th century (Oda, 1999). However, it was not the workers' well-being that was the main concern. The agreement about the revision of the unequal treaties between Japan and the countries concerned in 1894 together with Japan's victory over China in the Sino-Japanese war in 1985 provided a significant impetus for Japan's 
$\mathrm{JMH}$

20,4

400 industrialization (Sugiyama, 1968), and the subsequent rapid modernization and industrialization gave rise to a number of social problems (Nishizawa, 2012). The Meiji government promoted a developmental state policy following the Prussian way, and as early as 1882, it began studying Western examples of factory legislations, as it had done for other legal eras (Tackney, 2009). The government did so, however, less out of concern for the welfare of workers than out of a desire to improve industrial productivity. Needless to say, the liberalists categorically opposed any such law, and before 1900, Japanese bureaucrats lacked the insulation from business interests necessary to champion protectionist labor policies (Garon, 1987, p.18-19).

The need to improve workers' conditions for the further development of the national economy was also recognized by a group of scholars who formed the Shakai Seisaku Gakkai ("Japan's Society for the Study of Social Policy") in 1896. The Society was modeled after its German example, the Society for the Study of Social Problems, founded in 1872. Its goal was to promote studies that facilitated the state's active role in regulating work and industrial relations with the objective of helping the nation to develop and modernize as quickly as possible (Mouer and Kawanishi, 2005, p. 28). The ideas of the Society for the Study of Social Problems were introduced to Japan by Wadagaki Kenzō (1860-1919). Wadagaki taught economics and economic history at the Law College of the (Tokyo) Imperial University, the center for the dissemination of ideas from Germany in Japan (Nishizawa, 2012). In 1888, he published an article in which he refused both economic liberalism and socialism and instead argued for a third way that maintained an order based on private ownership and achieved social harmony through the action of individuals and the power of the state (Sugiyama, 1968; Nishizawa, 2012). In 1892-1893, Kanai Noboru, also a professor of economics at the Law College of the (Tokyo) Imperial University from 1890, wrote an article called "Genkon no Shakaiteki Mondai" ("The Present Social Questions"). These two articles were regarded "as events that "tolled the funeral bell of liberal economics and the daybreak bell of the new German economic thought' [...]” (Nishizawa, 2012, p. 310).

The bureaucrats' attempts to ameliorate working conditions borne out of their concern for the nation's competitiveness and the dissemination of the new German economic thought were not the only influences that led to discussions about factory law and, eventually to improvements in working conditions. Another important factor was the chronic labor shortage, a by-product of Japan's rapid industrialization. For example, in the textile industry, the first industry in Japan to adopt extensive factory production, the local supplies of labor to textile mills were exhausted by 1890 . Textile producers first responded with increased recruiting efforts (see above) but around 1910, they realized that it was more efficient for them to improve working conditions and to motivate workers and encourage them to stay longer rather than using coercive measures to force production up while incurring high expenses for supervision and recruiting (Taira, 1962).

Around the same time, the scientific management movement, also known as Taylorism, began to spread in Japan. Although certain prerequisites for the successful implementation of the movement first had to be put into place, as Hashimoto (2002) has shown, over time, Taylorism exerted a strong influence on the Japanese production system and had a lasting influence on Japanese management (Hashimoto, 2002; Vaszkun and Tsutsui, 2012). Some Japanese intellectuals criticized Taylorism for its alleged tendencies to deskill labor, increase individualism and emphasize production 
output at the expense of labor (Vaszkun and Tsutsui, 2012). Nevertheless, its adoption, adaptation and further development had a lasting and positive effect on the employer employee relationship. Tsutsui (1998) even argues that understanding the Taylorist heritage is essential for understanding the post-war "Japanese-style management".

The list of potential influences on labor relations in Meiji Japan does not end here. To cover them all in detail and to assess their impact would go beyond the scope of this article. Crucial for our understanding is that neither labor relations in Meiji Japan nor Japan's famed post-war labor-management relations were simply a continuation of a centuries-old cultural tradition, but rather the product of a multitude of factors, both indigenous and imported from abroad.

\section{Conclusion and implications for further research}

This article set out to explain the poor nature of industrial relations in Meiji Japan (1868-1911). In this section, we review the main findings and discuss directions for future research.

It has frequently been claimed that to understand the workings of the present-day Japanese economy in general and labor relations in particular, it is essential to understand Japan's centuries-old Neo-Confucianist heritage, whose values were broadly institutionalized within Japanese society during the Tokugawa era (1603-1867). Although research indicates the existence of such values in post-war Japan, their apparent absence in labor relations during Meiji Japan (1868-1911) is puzzling. Their lack has been explained by a temporary decline of Neo-Confucianism during Meiji Japan due to its close relationship to the ideology of the Tokugawa regime and the strong Westernizing tendencies of early Meiji era policies and thought. Others have attributed the absence to the fact that only the samurai elite, not the former commoners, espoused Neo-Confucianist values. Because both former samurai and many former commoners established new businesses, Neo-Confucianist values first had to enter labormanagement relations. We argue that so little of the Neo-Confucianist heritage is detectable in Meiji labor relations because it wasn't institutionalized in Tokugawa Japan in the first place.

Against this background, our key findings can be summarized as follows. Contrary to widespread belief, Neo-Confucianist values were not broadly anchored within Tokugawa society. Neo-Confucianism was not adopted as the state ideology from the beginning of the Tokugawa era, and later efforts to institutionalize its values were confined to the samurai class due to inadequate means and channels of reaching all layers of Tokugawa society. Moreover, there is evidence that Neo-Confucianist values were less anchored among the samurai class than generally assumed. Even the elite of the samurai class systematically neglected Neo-Confucianist duties, ignored hierarchies and regulations and disregarded loyalties.

In Meiji Japan, however, an imagined past of Neo-Confucianist tradition served as a plane for moral projections. Neo-Confucianist values were elevated to a fundamental element of compulsory public education and were used to buttress a powerful modern state with a nationalistic ideology. By the late Meiji era, such an imagined past had also entered the economic sphere and the discussions of factory regulations. At that time, however, it was still a rhetorical device with little substance. Labor relations, especially in early Meiji Japan, resembled closely those prevalent during Tokugawa Japan, when wage labor had expanded rapidly within a capitalist market economy. The introduction 
$\mathrm{JMH}$

20,4

402

of Western liberal economics in late Tokugawa and early Meiji Japan thought did not compete with a Neo-Confucianist heritage but rather reinforced the prevailing attitude about labor relations. Thus, Neo-Confucianism contributed much less to the cultural underpinnings of Japanese society in Tokugawa and Meiji Japan than commonly assumed. This conclusion leads to a number of implications for further research.

First, more effort is needed to increase our knowledge of prewar labor relations, especially late Tokugawa/early Meiji Japan, through original research as well as the reception of Japanese literature on this topic. This attempt will not only close the existing gap in Western research on Japan but will also enhance our understanding of how Japanese labor relations developed. For example, did labor relations in samurai households differ from those in merchant or peasant households? Did labor relations differ in towns and in the countryside, where wage labor also spread with the development of proto-industrialism?

Second, with regard to our understanding of Tokugawa Japan, the cultural underpinnings of the samurai class appear less straightforward than generally assumed. As we have shown, widely accepted assumptions about the importance and the influence of religious movements and intellectual currents must be further scrutinized to enhance our understanding of Tokugawa Japan. Assuming that values frame a person's actions, further research on the actual economic behavior in Tokugawa Japan is necessary. This research will complement and/or contrast with contemporary writings on normative ethics and will facilitate inferences about the cultural underpinnings of the samurai and commoners. Such research will also enhance our understanding of what enabled the spread of secular market capitalism in medieval and Tokugawa Japan. Did factors such as religion or intellectual currents have a supportive or inhibitive effect? With reference to Gerde et al. (2007), how and why did economic self-pursuit gain legitimacy among the samurai? Was an explicit or implicit moral cover used by the daimyo to justify economic self-pursuit?

Third, with regard to our understanding of post-war Japan and the Japanese economy, although we have fairly good knowledge of when, by whom and to what end Japan's ancient Neo-Confucianist traditions were invoked or rejected, the question remains of when these values were institutionalized to such a degree that they served as a motive for economic behavior. This question is of crucial importance because the notion of a centuries-old Neo-Confucianist heritage influencing economic behavior in Japan is widespread and forms the basis of many economic and business studies that have substantially shaped our view of the Japanese economy and Japan's firms and economic actors.

Fourth, in view of these conclusions, the question arises about the role of invented traditions in the development and dissemination of management theories in Japan as well as in other countries or cultural areas. How have invented traditions helped develop and legitimize certain management practices? What role have they played in a "fad" becoming a "paradigm" and, hence, an element in internally recognized management theory, as discussed by Towill (2006)? What elements need to be in place for an invented tradition to become accepted? Who propagates these invented traditions? We are confident that studying the history of management practices from the perspective of invented traditions will yield many more unexpected results.

Finally, more research is needed on the interaction between culture, economic behavior and institutions, in general. How does culture emerge? What determines the 
persistence of cultural traits? Under what circumstances do cultural traits influence behavior and institutions? Why, for example, did Neo-Confucianism allegedly matter in post-war labor relations in Japan and Korea (Seong, 2003; Kim et al., 2004; Kim, 2009), but not in China, another country with a so-called "Neo-Confucianist tradition" (Shen, 2008)? In tackling such questions, rigorous testing is essential (see for example Gong et al., 2013 and their empirical study of the effects of Chinese guanxi in strategic alliances) to prevent cultural explanations from being mere attempts to "claim the residuals" or ex-post rationalizations.

\section{Notes}

1. Culture is defined as "customary beliefs, values, and social constraints that ethic, religious, and social groups transmit fairly unchanged from generation to generation" (Guiso et al., 2006).

2. The term "invented tradition" refers to a set of practices seeking to inculcate certain values and norms of behavior by repetition in an attempt to establish continuity with a suitable historic past. See Hobsbawm (2012).

3. For the limitations and strengths of a case study approach, see Hayek et al. (2010).

4. This controversy on why the Japanese business elite invoked Neo-Confucianist tradition recalls on a similar discussion in literature regarding whether Southern paternalistic leadership style in the United States during antebellum slavery was benevolent or solely serving. See Hayek et al. (2010).

5. See Gerde et al. (2007) on religion as moral cover for the pursuit of economic self-interest.

6. Such is the case with Neo-Confucianism, as we have just seen, and such is also the case with, for example, the well-known Bushidō ("The Way of the Warrior"). Bushidō is widely regarded as the centuries-old code of behavior of the samurai class that was transmitted into modern Japan and became a fundamental concept of Japanese militarism before 1945 (Benesh, 2011). Bushidō, however, was largely unknown in Japan before the last decade of the 19th century. Modern Bushidō discourse began in the 1880s and reflected Japan's attempts to redefine itself with regard to the "foreign" (i.e. the West). Dissemination on a large scale began only after 1900, especially after the Russo-Japanese War of 1904-1905 (Nakamura, 2008). Within this context, Hagakure ("hidden by the leaves"), written in the early 19th century, became one of the most significant samurai texts only after its publication in the early 20th century (Nakamura, 2008; Benesh, 2011). Besides Confucianism, Buddhism and Shintoism are usually cited as major religions in Tokugawa Japan. Shintoism or Shinto (1"Way of the Gods") is regarded as a native religion of Japan. It is characterized by a set of indigenous practices, the veneration of nature spirits and ancestors, and a lack of formal dogma. It was first referred to in the 8th century, but despite these early roots Shintō cannot be treated as an independent religion due to its syncretic nature and its overlaps with Buddhism and Confucianism (Jansen, 2000, p. 217). For example, one school of thought maintained that the supreme goddess of Shintoism was a reborn Buddha, and another school of thought reversed this order (Oda, 1999, p. 26). What is more, it was only in late Tokugawa that many of these elements became structured into something called Shintō. Emerging from the umbrella of Buddhism, it was closely intermingled with folk religion and pieced together ancestor worship, portents, and direction. The beginning of Shintō as a state-related religion was marked by a governmental decree in 1868, which ordered the "separation of the gods and Buddhas" and was accompanied by outbursts of violence against Buddhist institutions (Antoni, 1995).

\section{Neo-Confucianism}


$\mathrm{JMH}$

20,4

404

7. After Japan was opened up by Commodore Matthew Perry (1794-1858), who had landed at Edo bay in 1853, Japan imported not only Western technology and products on an increasing scale but also Western ideas. In the field of economic thought, the liberal school of British origin was the dominant idea in the earlier years of Meiji Japan (Sugiyama, 1968).

8. Rangaku had emerged in the 17 th century as a consequence of the policy of national seclusion followed by the early Tokugawa shogunate. From 1639 to the 1850s, employees of the Dutch East India Company were the only Westerners allowed to enter Japan (Van Sant, 2012). Through Rangaku or Yögaku ("Western learning"), Western technology and methods were introduced to Japan. An official translation bureau commissioned by the bakufu and similar enterprises undertaken by various daimyo worked on the translation and collection of Dutch works on subjects such as medicine, chemistry, shipbuilding, mechanics, mining, mathematics, physics and pyrotechnics. Efforts to study the West were intensified after Commodore Perry landed in Edo Bay in 1853 (Smith, 1948).

\section{References}

Antoni, K. (1995), “The 'separation of Gods and Buddhas' at Ōmiwa shrine in Meiji Japan”, Japanese Journal of Religious Studies, Vol. 22 Nos 1/2, pp. 139-159.

Bellah, R.N. (1985), Tokugawa Religion: The Cultural Roots of Modern Japan, Collier Macmillan Publishers, New York, NY.

Benesh, O. (2011), "Bushido: the creation of a martial ethic in late Meiji Japan", Doctoral Thesis, The Faculty of Graduate Studies (Asian Studies), The University of British Columbia, Vancouver, BC, available at: http://circle.ubc.ca/browse?value $=$ Benesch $\% 2 \mathrm{C}+$ Oleg\&type $=$ author (accessed 21 August 2013).

Blind, G. (2012), "Investigating entrepreneurial spirit with the rule approach: why self-employment is on the decline in Japan”, Evolutionary and Institutional Economic Review, Vol. 9 No. 1, pp. 183-198.

Boardman, C.M. and Kato, H.K. (2003), "The Confucian roots of business Kyosei”, Journal of Business Ethics, Vol. 48 No. 4, pp. 317-333.

Bodart-Bailey, B. (1993), "The persecution of Confucianism in early Tokugawa Japan", Monumenta Nipponica, Vol. 48 No. 3, pp. 293-314.

Collins, R. (1997), "An Asian route to capitalism: religious economy and the origins of self-transforming growth in Japan”, American Sociological Review, Vol. 62 No. 6, pp. 843-865.

Crawcour, S. (1989), "Economic change in the nineteenth century", in Jansen, M.B. (Ed.), The Cambridge History of Japan. Vol. 5, The Nineteenth Century, Cambridge University Press, Cambridge, pp. 569-617.

DiMaggio, P. (1994), "Culture and economy", in Smalser, N. and Swedberg, R. (Eds), The Handbook of Economic Sociology, Princeton University Press, Princeton, pp. 27-57.

Dore, R.P. (1965), Education in Tokugawa Japan, University of California Press, Berkeley, CA.

Dyck, B., Starke, F.A. and Weimer, J.B. (2012), "Toward understanding management in first century Palestine", Journal of Management History, Vol. 18 No. 2, pp. 137-165.

Fujimori, M. and Ouchi, A. (1996), "Uchi shakai no ronri: nihon kigyō keiei no soko ni nagareru mono (Uchi-Society: Its Historical Background and Japanese Management)”, Mita Business Review, Vol. 39 No. 2, pp. 51-70.

Furuya, M. and Shiina, I. (1991), "Edo jidai no shōgyō katsudō no hatten to shōnin no gōriteki seishin (The development of commercial activities and rational thought among merchants 
within edo period economic structure)", The Chuo-Gakuin University Review of Economics \& Commerce, Vol. 6 No. 1, pp. 25-47.

Garon, S.M. (1987), The State and Labor in Modern Japan, University of California Press, Berkeley.

Gerde, V.W., Goldsby, M.G. and Shepard, J.M. (2007), "Moral Cover For Capitalism: The Harmony-Of-Interests Doctrine”, Journal of Management History, Vol. 13 No. 1, pp. 7-20.

Gong, B., He, X., Hsu, H.-M. (2013), "Guanxi and trust in strategic alliances", Journal of Management History, Vol. 19 No. 3, pp. 363-376.

Gordon, A. (1998), “The Invention of Japanese-Style Labor Management”, in Vlastos, S. (Ed), Mirror of Modernity Invented Traditions of Modern Japan, University of California Press, Berkeley, pp. 19-36.

Guiso, L., Sapienza, P. and Zingales, L. (2006), “Does culture affect economic outcomes?”, The Journal of Economic Perspectives, Vol. 20 No. 2, pp. 23-48.

Hall, J.W. (1974), “Rule by status in Tokugawa Japan”, Journal of Japanese Studies, Vol. 1 No. 1, pp. 39-49.

Ham, C. (2004), “The ironies of Confucianism”, Journal of Democracy, Vol. 15 No. 3, pp. 93-107.

Hashimoto, T. (2002), "Punctuality and the introduction of scientific management to Japan", Japan Review, Vol. 14, pp. 99-118.

Hayek, M., Novicevic, M.M., Humphreys, J.H. and Jones, N. (2010), "Ending the denial of slavery in management history", Journal of Management History, Vol. 16 No. 3, pp. 367-379.

Henshall, K.G. (1999), A History of Japan: From Stone Age to Superpower, Palgrave Macmillan, Basingstoke.

Hill, C. (1995), "National institutional structures, transaction cost economizing and competitive advantage: the case of Japan”, Organization Science, Vol. 6 No. 1, pp. 119-131.

Hobsbawm, E.J. (2012), "Introduction: inventing traditions", in Hobsbawm, E.J. and Ranger, T. (Eds), The Invention of Traditions, Cambridge University Press, Cambridge, pp. 1-14.

Hofstede, G. and Bond, M.H. (1988), "The Confucius connection: from cultural roots to economic growth”, Organizational Dynamics, Vol. 16 No. 4, pp. 5-21.

Honjo, E. (1939), "Economic thought in the early period of the Tokugawa era", Kyoto University Economic Review, Vol. 14 No. 4, pp. 1-17.

Horie, Y. (1962), “Confucian concept of state in Tokugawa Japan”, Kyoto University Economic Review, Vol. 32 No. 2, pp. 26-38.

Hull, B. and Bold, F. (2013), "Religion, warrior elites, and property rights", Economics Working Paper, Department of Social Sciences, College of Arts, Sciences, and Letters, University of Michigan-Dearborn, available at: http://hdl.handle.net/2027.42/96847 (accessed 14 August 2013).

Jacobs, A.J. (2010), "Max Weber was right about the preconditions, just wrong about Japan: the Japanese ethic and its spirit of capitalism", The Open Area Studies Journal, Vol. 3, pp. 12-29.

Jansen, M.B. (2000), The Making of Modern Japan, Belknap Press of Harvard University Press, Cambridge, MA.

Jansen, M.B. and Stone, L. (1967), "Education and modernization in Japan and England", Comparative Studies in Society and History, Vol. 9 No. 2, pp. 208-232. 
$\mathrm{JMH}$

20,4

406

Kawaguchi, H. (2010), "Economic thought concerning freedom and control", in Gramlich-Oka, B. and Smits, G. (Eds), Economic Thought in Early Modern Japan, Brill, Leiden, pp. 47-66.

Kim, D.-O-, Bae, J.-S. and Kim, T.-W. (2004), Employment Relations and HRM in South Korea: In a Time of Change (Explorations in Asia Pacific Business Economics), Ashgate Publishing Limited, Surrey.

Kim, T. (2009), "Confucianism, modernities and knowledge: China, South Korea and Japan”, in Cowen, R., Kazamias, A.M. and Unterhalter, E. (Eds), International Handbook of Comparative Education, Springer Science+Business Media, Berlin, pp. 857-872.

Kinmonth, E.H. (1978), "Fukuzawa reconsidered: Gakumon no susume and its audience", The Journal of Asian Studies, Vol. 37, pp. 677-696.

Kiyota, M. (1966), "Meiji Buddhism: religion and patriotism”, Asian Studies, Vol. 4 No. 1, pp. $49-58$.

Kobayashi, T. (1965), "Tokugawa education as a foundation of modern education in Japan", Comparative Education Review, Vol. 9 No. 3, pp. 288-302.

Komiyama, T. (2006), "Waga kuni no shōgyō no kyōiku no hensen to shōgyō dōtoku no kōsatsu (The history of business education: a view on business ethic)", Aichi Gakuin Daigaku Rongi Shōgaku Kenkyū, Vol. 47 Nos 1/2, pp. 39-63.

Leupp, G.P. (1992), Servants, Shophands, and Laborers in the Cities of Tokugawa Japan, Princeton University Press, Princeton, NJ.

Lidin, O.G. (1999), Ogyū Sorai's Discourse on Government (seidan): An Annotated Translation, Harrassowitz Verlag, Wiesbaden.

Long, W.A. and Seo, K.K. (1977), Management in Japan and India, with Reference to the United States, Praeger, New York, NY.

Maruyama, M. (1974), Studies in the Intellectual History of Tokugawa Japan, Princeton University Press, Princeton, NJ.

Mathias, R. (2011), "Japan in the seventeenth century: labour relations and work ethics", International Review of Social History, Vol. 56 No. S19, pp. 217-243.

Morishima, M. (1982), Why has Japan Succeeded?: Western Technology and the Japanese Ethos, Cambridge University Press, Cambridge.

Mouer, R. and Kawanishi, H. (2005), A Sociology of Work in Japan, Cambridge University Press, Cambridge.

Nakamura, J.I. and Miyamoto, M. (1982), "Social structure and population change: a comparative study of Tokugawa Japan and Chi' ing China", Economic Development and Cultural Change, Vol. 30 No. 2, pp. 229-269.

Nakamura, Y. (2008), "Bushidō-Diskurs: Die Analyse der Diskrepanz zwischen Ideal und Realität im Bushidō-Diskurs aus dem Jahr 1904”, Doctoral Thesis, University of Vienna, available at: http://othes.univie.ac.at/3182/ (accessed 21 August 2013).

Nishizawa, T. (2012), "The emergence of economic science in Japan and the evolution of textbooks 1860s-1930s", in Augello, M.M. and Guidi, E.L. (Eds), The Economic Reader. Textbooks, Manuals and the Dissemination of the Economic Sciences During the Nineteenth and Early Twentieth Centuries, Routledge, New York, NY, pp. 305-324.

Oda, H. (1999), Japanese Law, 2nd ed., Oxford University Press, Oxford.

Ooms, H. (1984), "Neo-Confucianism and the formation of early Tokugawa ideology", in Nosco, P. (Ed.), Confucianism and Tokugawa Culture, Princeton University Press, Princeton, NJ, pp. 27-61. 
Ooms, H. (1985), Tokugawa Ideology: Early Constructs, 1570-1680, Princeton University Press, Princeton, NJ.

Ornatowski, G.K. (1996), "Confucian ethics and economic development: a study of the adaptation of Confucian values to modern Japanese economic ideology and institutions", The Journal of Socio-Economics, Vol. 25 No. 5, pp. 571-590.

Ornatowski, G.K. (1998), "On the boundary between "religious" and "secular": the ideal and practice of neo-Confucian self-cultivation in modern Japanese economic life", Japanese Journal of Religious Studies, Vol. 25 Nos 3/4, pp. 345-376.

more, K. (2012), "The nationalization of Confucianism: academism, examinations, and bureaucratic governance in the late Tokugawa state", Journal of Japanese Studies, Vol. 38 No. 1, pp. 25-53.

Pascale, R.T. and Athos, A.G. (1981), The Art of Japanese Management: Applications for American Executives, Simon and Schuster, New York, NY.

Preble, J.F. and Hoffman, R.C. (2012), "General management of innovation: lessons from the shaker community”, Journal of Management History, Vol. 18 No. 1, pp. 24-45.

Rost, K., Inauen, E., Osterloh, M. and Frey, B.S. (2010) “The corporate governance of benedictine abbeys: what can stock corporations learn from monasteries?", Journal of Management History, Vol. 16 No. 1, pp. 90-115.

Rozman, G. (1974), "Edo's importance in the changing Tokugawa Society", Journal of Japanese Studies, Vol. 1 No. 7, pp. 91-112.

Rubinger, R. (1986), "Education: from one to room to one system”, in Jansen, M.B. and Rozman, G. (Eds), Japan in Transition, from Tokugawa to Meiji, Princeton University Press, Princeton, NJ, pp. 195-230.

Sawa, T. (1999), "Kinsei jugaku seiji shisō: Fujiwara Seika to Hayashi Razan, oyobi sono monryū (The realization of Confucianism political thought in premodern Japan: Seika Fujiwara, Ranzan Hayashi and Their Schools)", Journal of the Faculty of Political Science and Economics, Vol. 31, pp. 59-89.

Seong, H.C. (2003), "Modern Chinese Confucianism: the contemporary neo-Confucian movement and its cultural significance", Social Compass, Vol. 50, pp. 481-491.

Shen, J. (2008), "The characteristics and historical development of labour disputes in China", Journal of Management History, Vol. 14 No. 2, pp. 161-173.

Smith, T. (1948), "The introduction of western industry to Japan during the last years of the Tokugawa period", Harvard Journal of Asiatic Studies, Vol. 11 Nos 1/2, pp. 130-152.

Smith, V.O. and Smith, Y.S. (2011), "Bias, history, and the protestant work ethic", Journal of Management History, Vol. 17 No. 3, pp. 292-298.

Song, N.R. (1970), "Educational modernization in Tokugawa Japan: the case of Kagahan", Comparative Education Review, Vol. 14 No. 2, pp. 144-151.

Sours, M.H. (1982), “The influence of Japanese culture on the Japanese management system”, in Schwendiman, G. and Lee, S.M. (Eds), Japanese Management: Cultural and Environmental Considerations, Praeger, New York, NY.

Subhash, D. (1990), "The influence of Confucianism and zen on the Japanese organization", Akron Business and Economics Review, Vol. 21 No. 2, pp. 31-45.

Sugiyama, C. (1968), "The development of economic thought in Meiji Japan”, Modern Asian Studies, Vol. 2 No. 4, pp. 325-341.

Tackney, G.T. (2009), "Ye shall know them by their fruits", Journal of Management History, Vol. 15 No. 2, pp. 178-197. 
$\mathrm{JMH}$

20,4

408
Taira, K. (1962), “Characteristics of Japanese labor markets”, Economic Development and Cultural Change, Vol. 10 No. 2, pp. 150-168.

Takemura, E. (1997), The Perception of Work in Tokugawa Japan, University Press of America, Boston, MA.

Takenaka, Y. (1969), "Endogenous formation and development of capitalism in Japan”, The Journal of Economic History, Vol. 29 No. 1, pp. 141-162.

Tanaka, K. (1990), “'Terakoya' no kigen to gogen o megutte (On the origin and the etymology of 'Terakoya'), Philosophy, Vol. 91, pp. 527-546.

Towill, D.R. (2006), "Fadotomy - anatomy of the transformation of a fad into a management paradigm”, Journal of Management History, Vol. 12 No. 3, pp. 319-338.

Tsutsui, W.M. (1998), Manufacturing Ideology: Scientific Management in Twentieth-Century Japan, Princeton University Press, Princeton, NJ.

Uematsu, T. (1995), "Jugakusha no seisaku teigen (The policy proposals of Japanese Confucianists)", Kokumin Keizai Zasshi, Vol. 172 No. 5, pp. 19-44.

Van Sant, J.E. (2012), "Rangaku medicine and 'Foreign' knowledge in late Tokugawa Japan”, Southeast Review of Asian Studies, Vol. 34, pp. 207-214.

Vaszkun, B. and Tsutsui, W.M. (2012), "A modern history of Japanese management thought", Journal of Management History, Vol. 18 No. 4, pp. 368-385.

Vesey, A. (2004), "For faith and prestige: daimyo motivation for Buddhist patronage", Early Modern Japan, Vol. 12 No. 2, pp. 53-67.

Weber, M. (1958/1920), The Protestant Ethic and the Spirit of Capitalism, Charles Scribner's Sons, New York, NY.

Whitehill, A.M. (1992), Japanese Management: Tradition and Transition, Routledge, London, New York.

Yamamura, K. (1997), The Economic Emergence of Modern Japan, Cambridge University Press, Cambridge.

Yoshimura, T. (2003), "A note on the formation of social stratification system in early modern Japan”, Kumamoto Journal of Culture and Humanities, Vol. 78, pp. 135-158.

Yoshioka, S. (1993), "The attitude towards accepting Confucianism in the early Tokugawa period", The Journal of Ryutsu Keizai University, Vol. 27 No. 3, pp. A1-A13.

\section{Further reading}

Elisonas, J. (1991), "Christianity and the Daimyo", in Hall, J.W. (Ed) The Cambridge History of Japan. Volume 4, Early Modern Japan, Cambridge University Press, Cambridge, pp. 301-372.

Gordon, A. (2003), A Modern History of Japan: From Tokugawa Times to the Present, Oxford University Press, New York, NY.

Katzner, D.W. (2008), Culture and Economic Explanation: Economics in the US and Japan, Routledge, London, New York, NY.

\section{Corresponding author}

Stefania Lottanti von Mandach can be contacted at: stefania.lottanti@aoi.uzh.ch

To purchase reprints of this article please e-mail: reprints@emeraldinsight.com Or visit our web site for further details: www.emeraldinsight.com/reprints 